\title{
VIOLENCE, SUBCULTURE, AND YOUTH GANG IN YOGYAKARTA, INDONESIA POST ERA OF NEW ORDE
}

Tassana Nualsomsri*

(Walailak University, Thailand)

\begin{tabular}{|c|c|}
\hline A R T I C L E I N F O & A B S T R A C T \\
\hline $\begin{array}{l}\text { Keyword: } \\
\text { violence, } \\
\text { subculture, } \\
\text { youth gang, } \\
\text { post era of the new orde }\end{array}$ & $\begin{array}{l}\text { The research article entitled "Violence, Subculture, and Youth Gang in Yogyakarta } \\
\text { Indonesia Post Era of the New Orde " aims to study the formation of adolescents in } \\
\text { the city of Yogyakarta. The gangs are influential, and the patterns of activity generated } \\
\text { by these groups often lead to violence. The emergence of many teen gangs in } \\
\text { Indonesia and in the city of Yogyakarta after the New Orde era showed that the } \\
\text { development and changes of these groups were not the results of government support } \\
\text { as was evident in the New Orde era, but these youth were formed by several factors, } \\
\text { mainly social factors, Indonesia's politics, and economy were increasingly complicated } \\
\text { during the New Orde transition period. The results of this study found that the } \\
\text { emergence of juvenile gangs in the city of Yogyakarta strengthens the culture of } \\
\text { violence that has long been taking place in Indonesian society. Meanwhile, the } \\
\text { education area of the city of Yogyakarta after the New Orde era has become a } \\
\text { reflection of the problem. Coupled with the context of change as a result of several } \\
\text { factors, namely economic factors, socio-cultural, religious, and others. }\end{array}$ \\
\hline
\end{tabular}

\section{INTRODUCTION}

The Yogyakarta city is an area where the growth and dynamics of changes in criminal groups and the ongoing culture of violence can be seen, as one of the important economic centers in Indonesia, especially income from tourism. Post- era of New Orde until now, Yogyakarta has developed into the second largest tourist destination after Bali, so that the city of Yogyakarta is rapidly developing, especially in the expansion of urban areas which causes a reduction in rural areas. So, it can be concluded that economic growth after the Asian economic crisis in 1997-1998 was quite fast, and the integration of various ethnic groups that came to Yogyakarta for business and education opportunities. This has caused Yogyakarta to be a reflection of the main social system of the Indonesian state which has ethnic and religious diversity. On the other hand, the city was once the center of Indonesia's struggle for independence in the war against the Dutch colonialists. During the war and after the end of World War II, the city of Yogyakarta has become the center of the emergence of several community organizations, such as the most influential group of religious organizations in Indonesia, Muhammadiyah, which was founded in 1912 and remains an influential group and plays an important role in social politics in Yogyakarta and Indonesia until now.

The economic crisis that began in 1997 had a major impact on the Indonesian people, especially adolescents and men who had difficulty finding employment at that time. This problem appears to be related to the increase in the number of criminals that have occurred throughout Indonesia and is seen increasingly clearly during the transition to the Reformation era after the New Orde regime. Although the development of democracy as a whole has become a positive side in the Reformation Era, on the other

\footnotetext{
* Corresponding author.

E-mail addresses: tad nuan@hotmail.com (Tassana Nualsomsri)
}

ISSN : 2597-7385 (Online) - ISLLAC : Journal of Intensive Studies on Language, Literature, Art, and Culture is licensed under Creative Commons Attribution-ShareAlike 4.0 International License (http://creativecommons.org/licenses/BY/4.0/). 
hand, it shows that the weakness of state power and law enforcement causes many acts of violence in the streets of big cities which are important economic centers throughout Indonesia, including the city of Yogyakarta. Yogyakarta has become an area where many mobs and youth gangs are formed by various factors. For example, economic growth, especially tourism and competition between regional political parties. The interesting thing is that these teenagers mostly deal with Islamic leaders and use religious teachings to legitimize acts of violence. This is one example of the complexity of crime and the creation of a culture of violence through various groups in Yogyakarta.

Therefore, the case of the formation of youth groups that took place in Yogyakarta can show that the development and transformation of the group did not result from state support as seen in the past. In contrast, the youth group was formed from increasingly complex factors, especially after the New Orde. This has led to research efforts aimed at responding to the emergence of a culture of violence in Yogyakarta after the New Orde which might have an effect from several factors such as economic, sociocultural, religious, and so on.

\section{THE CULTURE OF VIOLENCE IN INDONESIA AND CONTEMPORARY YOGYAKARTA}

Meanwhile, the study of the various motives of violence that occurred during the New Orde era, especially violence originating from the use of government power or violent support by a group of government-formed organizations, is often seen as groups of organizations established or supported by the state to use internal violence. addressing Indonesian social problems that are often controlled by the state (Ryter 2009; Collins 2002;) information that supports this argument is because in the New Orde era there were limits to the use of violence by groups of adolescents and influential organizations so that the state could control the use of violence by groups to achieve peace and as an attempt to monopolize social control by the government itself, thus, organizations at that time need to change the direction of group actions in ways that conflict with government policies. One of the main tactics is an adaptation or accepting as part of state power, not contradictory so that the organization can still exist in that era, as can be seen from the case of the Pancasila youth group that has been explained.

However, in the view of researchers in the New Orde era, what was interesting was the emergence of many influential youth groups and organizations throughout Indonesia. This can be seen from the movements or activities of these groups more freely than the Reformation era. Because, even though the government is very powerful, there is still an attitude of favoritism, a patronage system that allows gangsters to find a lot of exploitation if they can connect with the military or local politicians and make bribes, especially groups called Preman, groups that are part of the government will rule and legitimize using more violence.

After the end of the New Orde era led by Suharto in 1998, he entered the era of Reformation in Indonesian social politics. Characteristics of criminal groups and violence began to change more. With an appearance that has revealed a growing division of the patronage system between political elites and violent networks. With these criminal groups and violence, they began to transform themselves into religious vigilantes, ethnic movement organizations (ethnic empowerment organizations), local security providers or political and political party support groups, etc. (Wilson 2014: 290).

In addition, in the case of Indonesia, most criminal and violent groups have not been supported by the state as in the previous era. On the other hand, many of these groups reject the authority of the government, as a result of being ignored by the government. Some of the reasons are the failure of the decentralization process in a democratic system that is expected to improve the quality of life of rural communities. However, on the contrary, this resulted in the migration of rural residents wandering into the city in search of better living opportunities. The influence of migration of these people has caused tensions in the struggle for resources or infrastructure in limited urban areas, this has encouraged people to live in slums. This is an important factor that has led to the emergence of groups of adolescents, criminals or local armed groups in retaliation for government policies or as a result of ongoing conflicts between ethnic groups in Indonesia. Including the formation of groups employed to protect the interests of the authorities (Hagedorn 2008 quoted in Wilson 2014: 290).

What is interesting for the emergence of a group of teen gangs and ruling groups at the end of the New Orde era is the clear ambiguity between groups (formed by the government) with groups that have no clear organization. However, the emergence of these two groups can show the efforts to form their own groups to safeguard their own security and communities with important living quarters. This 
phenomenon occurred after the New Orde era can be explained by a long tradition in Indonesian social mentioned 'street justice' (street justice) is based on violence from people who influence an area. Including the use of groups or organizations above the law by the government or political elites on Indonesian social issues.

Therefore, the continuing violence and pattern changed from before the era of Indonesia's social, political and economic transformation from the New Orde era to the Reformation era, it was a change during the fall of state power under Suharto's leadership and at the beginning of the reform era, where power - the strength of the state as previously weakened. This provides an opportunity for organizations that have been protected by state power and elites to become more independent. In line with the volatility of the Indonesian economy which has remained unstable during the transition period, this has become one of the main factors causing many unemployed young people in big cities so that they feel anxious about their future and begin to feel a lack of social status. which causes integration to seek support, motivate, and boast of their own group identity.

Another interesting issue in the study of changes in the phenomenon of the emergence of most influential adolescent groups in Indonesia after the New Orde was Social Reformation in Indonesia, although influential adolescents began to exist since the New Orde era, at this time the number of adolescents or gangs affected increase. One of the prominent characters of this gang is that they often group based on religious and ethnic identity points. But it seems that the violence that occurred from these organizations was considered a social phenomenon in Indonesia at the time, this was proven only during the initial stages of the process leading to the Reformation era due to a number of factors, as seen in many studies, for example Emmerson (2002) discussed the cause of the widespread reappearance of violence throughout Indonesia after the New Orde era with the main cause was the failure of the state judiciary where the state could not provide equal, fair and equal protection for Indonesian citizens, this led to corruption among officials, politicians, and bribe officials.

In addition, another reason for these problems is the weakening of the military or army and police that are different from the New Orde era where they could play a very important role in maintaining President Soeharto's power through "ABRI Function" which has responsibility for two important things, namely, First, the military is responsible for protecting the country from external aggression. Secondly, the army also has the duty to maintain orde in Indonesian society. Therefore, at that time the role of the army had strength in the areas of Social, Economic and Political. And how to manage state peace with the guiding principle of violence. Therefore, during the New Orde era, the problem of religious and ethnic conflict in Indonesian society led to a little violence because the government often used violence in dealing with such conflicts. But when Indonesia entered the transition from the New Orde era to the Reformation era, one of the major changes that directly affected military institutions was the call for military reform by reducing the size and role of the army when the era of democracy developed. Therefore, at the beginning of the reform era, the army limited its role in politics, society, and economic. This has led to a wider variety of forms of violence in Indonesian society including ethnic and religious conflicts. Armed group movements, religious extremists or the appearance of many gangs.

The last important issue was severe economic fluctuations in Indonesia which began with the crisis in Asia in 1997. That caused other problems in Indonesian society such as poverty, unemployment, family problems, crime, violence, and others. These factors have encouraged so many people that they have not been able to adjust to changes in Indonesian society, and have led to the formation of influential gangs to protect their own interests, especially in big cities. (Alcano 2014; Wilson 2010; Kristiansen 2003; Schwarz 2004; Beazley 2002,2003a: b).

However, after the era of the Reformation passed, the institutions of cities in Indonesia have become stronger, including more stringent laws. Understanding democracy causes people to be more aware of their rights and values, as well as Indonesian society at that time. So that Indonesian society becomes increasingly reformed in turn to have a significant effect on various types of violence in Indonesia, both actions taken by the government or groups of organizations that move around Indonesia are controlled.

The next problem to consider is not to mean that greater civilian control over the use of violence from various groups will influence the decline of influential gangs, but changes will begin to appear in the status and role of groups in a direction intended to reduce violence. While the decision to join these influential groups of youth and youth in the next era there were other reasons for the assessment of the 
differences applied including violence. To find out their new description with groups of teenagers in Yogyakarta and throughout Indonesia, most of them may not have the problem of poverty or household damage has happened to other generations before that, for example, needing friends, the need to create an identity or stand alone in the community, feeling proud, etc.

Based on case studies from two influential gangs in Yogyakarta, QZRUH, and JOXZIN it can be said that members of these two groups were gathered for various purposes. For example, to fight social injustice, especially injustice and violence that arise and spread in the wider community, both from the government and from the social structure. While in socialist terms, it is said that, in fact, most QZRUH gang members are based on capable families. But most members of this group are not interested in living a normal life like family in general, but this group of teenagers chooses to live stunningly through activities that come from a combination of various forms. This often causes fighting and violence against other antagonist gangs. Another interesting thing about this gang is its influence, they are groups that are not based on religious ideologies such as Islamic groups such as gangs, generations, or many influences in Indonesian society.

While most members of JOXZIN have a santri background, this is defined by an anthropologist named Clifford Geertz. Santri is a community group that is very devout in Islam. Therefore, activities that do not lead to violence, or activities that lead to violence, are often described as acts of defense of religion or commonly called religious defense wars (jihad).

Besides that, in political ideology. Both groups have demonstrated the political expression of the ideology they support. It can be said that the QZRUH group was a key movement in supporting the Indonesian Democratic Party (PDI) and many QZRUH members became members of the PDI or to support the Golkar party which became the leading party in the New Orde era. This movement supports political parties in the Yogyakarta region, especially in the pre-election period. This group will be the main force in finding supporters of political parties including the use of dirty methods. To destroy the base or choose opposition political parties. While the JOXZIN group was known to support the United Development Party (PPP) because most group members came from regions that supported the PPP party in Yogyakarta. The JOXZIN group, as well as the QZRUH group, became a major part of local politics in Yogyakarta, as a movement to campaign for the party and find ways to destroy the opposition in any way. However, the similarity between the two groups is the political and ethnic identity of the two groups which are also anti-Chinese people in Yogyakarta, although they do not lead to violence as happened between the two groups.

\section{CONCLUSION}

Although the atmosphere and political violence during Indonesia's political transition in Yogyakarta will not lead to violence as happened in other parts of Indonesia. But Yogyakarta after entering the reform era still faces economic problems in recovering from the Asian crisis. Research on economic change in Indonesian society in the same vein can show that Indonesia after the New Orde era has faced a number of large-scale urban unemployment problems that have been affected by the 1997 economic crisis many people migrated to major cities in Indonesia for long-term economic opportunities. Since the 1980s, under government policies that wanted to bring Indonesia into industrial development in the era of President Soeharto's New Orde, the policy made the overall quality of life for Indonesian people increase. Although the political and social context was still under the domination and monopoly of Suharto and his followers. However, when Indonesia faced the severe Asian economic crisis which was one of the main reasons for Soeharto's resignation from the presidency with political turmoil and violence in the transition from the new orde era to the Reformation era.

With the social, political and economic characteristics of Indonesia, social change has emerged from the New Orde era. Although on the one hand, the reform era also accompanied democratic liberalism and progressive freedom. But on the other hand, the moment of social, political and economic transformation has revealed an increase in the level of violence and crime in Indonesian society. Like the emergence of influential groups. Youth gangs and extremist religious movements. This phenomenon can be said to be a product of major structural changes beyond the control of the government. and can reflect the failure of decentralization and the economic prosperity of the government, especially in urban areas. Therefore, urban areas have seen the emergence of ghettos, poor or degraded areas in major cities throughout Indonesia. This area can show inadequate infrastructure. Social welfare includes not strong 
enforcement because, on the one hand, it can reflect that the government itself cannot control or assist these fields effectively. That's where the efforts of various groups are influenced by social structures. This causes the formation of self-organized groups to survive.

\section{REFERENCES}

Alcano, M.C. (2014). 'Youth Gangs and Streets in Surabaya, East Java: Growth, Movement and Places in the Context of Urban Transformations.' Antropologia, Vol. 1(1): 33-58.

Beazley, H. (2002). 'Vagrants Wearing Make-up: Negotiating Spaces on the Streets of Yogyakarta, Indonesia'. Urban Studies, Vol 39(9): 1665-1683.

- (2003). 'Voices from the Margins: Street Children's Subcultures in Indonesia'. Children's Geographies. Vol.1 (2): 181-200.

Emmerson, D. K. (ed). (1999). Indonesia beyond Subarto: Polity, Economy, Society, Transition. Armonk, NY: M.E. Sharpe.

Kristiansen, S. (2003). Violent Youth Groups in Indonesia: The Cases of Yogyakarta and Nusa Tenggara Barat. Journal of Social Issues in Southeast Asia 18(1): 110-138.

Ryter, L. (2009). "Youth Gangs and Otherwise in Indonesia" paper presented for the Global Gangs Workshop in Geneva, 14-15 May 2009.

Wilson, I. (2014). "Testing the Boundaries of the State: Gangs, militias, Vigilantes and violent entrepreneurs in Southeast Asia." Richard Robinson (ed.) Routledge Handbook of Southeast Asian Politics. London and New York: Routledge.

(2010). The Biggest Cock: Territoriality, Invulnerability, and Honour amongst Jakarta's

Gangsters. Indonesian Studies Working Paper. The University of Sydney. 